\title{
Г. Г. КАЗАРЯН
}

кандидат економічних наук, директор,

Асоціація «Всеукраїнська спілка протезно-ортопедичних підприємств «Ортонет»

\section{СТРУКТУРНО-ФУНКЦІОНАЛЬНА МОДЕЛЬ ІНСТИТУЦЙНОГО РЕГУЛЮВАННЯ СИСТЕМИ СОЦІАЛЬНО-ЕКОНОМІЧНОГО ЗАБЕЗПЕЧЕННЯ ОСІБ З ІНВАЛІДНІСТЮ}

Казарян, Г. Г. Структурно-функціональна модель інституційного регулювання системи соціальноекономічного забезпечення осіб з інвалідністю [Текст] / Г. Г. Казарян // Економічний аналіз: зб. наук. праць / Тернопільський національний економічний університет; редкол.: О. В. Ярощук (голов. ред.) та ін. - Тернопіль: Видавничо-поліграфічний центр Тернопільського національного економічного університету «Економічна думка», 2017. - Том 27. - № 3. - С. 248-253. - ISSN 1993-0259.

\section{Анотація}

В статті розроблено структурно-функціональну модель інституційного регулювання системи соціально-економічного забезпечення осіб з інвалідністю, яка адаптована до умов функціонування національної економік.

Ключові слова: соціально-економічного забезпечення; осіб з інвалідністю; модель; регулювання.

\author{
G. G. KAZARIAN \\ PhD in Economics, \\ Director,
}

Association "All-ukrainian Union of Prosthetic and Orthopedic Enterprises "Ortonet"

\section{STRUCTURAL AND FUNCTIONAL MODEL OF INSTITUTIONAL REGULATION OF THE SYSTEM OF SOCIAL AND ECONOMIC PROVISION OF PERSONS WITH DISABILITIES}

\begin{abstract}
The structural and functional model of institutional regulation of the system of social and economic provision of persons with disabilities is developed in this research. This model is adapted to the conditions of national economies functioning.
\end{abstract}

Keywords: social and economic provision; persons with disabilities; model; regulation.

\section{JEL classification: L31}

Структура державних інститутів системи соціально-економічного забезпечення осіб 3 інвалідністю в Україні є досить складною та громіздкою з надмірною ієрархією та централізованим державним управлінням; інститути системи соціально-економічного забезпечення осіб з інвалідністю за ознаками належності до суспільних секторів можна вирізнити (з урахування специфіки такої системи) в державні та виконавчі (недержавні), а відповідно до територіальної ознаки функціонування такої системи - загальнодержавні та регіональні; надання соціальних послуг у напрямку соціальноекономічного забезпечення осіб з інвалідністю віднесено до компетенцій значної кількості центральних органів виконавчої влади, що в умовах відсутності ефективного механізму фінансування та інших інструментів державного регулювання системи соціально-економічного забезпечення, що призводить до дуже низьких рівнів його якості, доступності та обсягів задоволення осіб з інвалідністю.

Формування механізму інституційного регулювання соціально-економічного забезпечення осіб 3 інвалідністю розглядали в наукових працях Галицький О. М., Гонта О. І., Гришова І. Ю., Дяченко О. П., Мельник О. Г., Мищак I. М., Наумова Л. М., Стоянова-Коваль С. С., Шестаковська Т. Л. [1-16]. Проте державне регулювання соціального захисту осіб з інвалідністю залишається неефективним та таким, що потребує трансформацій його державних механізмів.

Безпосередню участь у реалізації системи соціально-економічного забезпечення осіб з інвалідністю бере такий інститут як Державна служба зайнятості, діяльність якої координується Міністерством соціальної

(C) Г. Г. Казарян, 2017 
політики та є централізованою системою державних установ в областях, містах, районах у містах, а також у містах та районах, навчальних закладів державної служби зайнятості, центрів професійної орієнтації населення, інших підприємств, установ, організацій, які надають послуги щодо працевлаштування (пошук роботи, яка підходить під фізичні можливості інваліда; сприяння у працевлаштуванні та соціальному супроводженні влаштованої на роботу особи з інвалідністю). Тобто державна служба зайнятості виконує завдання та функції у сфері зайнятості осіб з інвалідністю, їх соціального захисту від безробіття, а також функції виконавчої дирекції Фонду загальнообов'язкового державного соціального страхування на випадок безробіття [9]. Тобто, державна служба зайнятості володіє інструментами та заходами щодо сприяння зайнятості осіб 3 інвалідністю шляхом надання інформаційних, консультаційних та профорієнтаційних послуг, організації інклюзивного професійного навчання, формування бази вакансій та пошуку роботи, працевлаштування тощо. Зазначимо, що державна служба зайнятості надає послуги з працевлаштування на безоплатній основі, а ії діяльність фінансується за рахунок передбачених на такі цілі коштів з Фонду загальнообов'язкового державного соціального страхування на випадок безробіття.

Міністерство соціальної політики України також координує та контролює діяльність Фонду соціального захисту інвалідів і Державної служби з питань інвалідів та ветеранів України. Фонд соціального захисту інвалідів $є$ бюджетною установою, основними завданнями якого є реалізація в межах своєї компетенції заходів щодо забезпечення зайнятості та працевлаштування інвалідів; виконання програм щодо соціального захисту інвалідів. До повноважень Фонду також належать питання працевлаштування інвалідів, ведення претензійно-позовної роботи у судах різних інстанцій, забезпечення інвалідів санаторно-курортними путівками, автомобілями, технічними та іншими засобами реабілітації, надання інформаційно-консультаційних послуг інвалідам та інші питання, які певною мірою пов'язані із соціально-економічним забезпеченням інвалідів.

Важливим інститутом соціально-економічного забезпечення осіб з інвалідністю $є$ державна служба з питань інвалідів та ветеранів України, яка також є центральним органом виконавчої влади та діяльність якої координується Кабінетом Міністрів України через Міністерство соціальної політики України. До основних завдань державної служби з питань інвалідів та ветеранів України в системі соціально-економічного забезпечення осіб з інвалідністю варто віднести розробку та внесення пропозицій Міністерству соціальної політики щодо формування державної політики у сфері соціальноекономічного забезпечення осіб з інвалідністю та реалізація цієї політики [10]. Для виконання цього завдання державною службою з питань інвалідів та ветеранів виконуються такі функції:

- щорічно подаються на розгляд Міністерству соціальної політики пропозиції щодо формування оптимальної ціни на засоби реабілітації, які виготовляються за індивідуальним замовленням;

- проводить моніторинг забезпечення інвалідів санаторно-курортними путівками, автомобілями, технічними та іншими засобами реабілітації;

- разом із громадським організаціями інвалідів проводить аналіз рівня доступності для інвалідів об’єктів житлово-комунального та громадського призначення, транспорту, інформації та зв'язку, а також інших об'єктів та послуг;

- надає центральним та місцевим органам виконавчої влади пропозиції щодо створення безперешкодного середовища для перебування інвалідів та ін.

На регіональному рівні функціонування системи соціально-економічного забезпечення осіб 3 інвалідністю грунтується на таких інститутах, як місцеві державні адміністрації, виконавчі органи місцевого самоврядування. Так, у ст. 23 Закону України «Про місцеві державні адміністрації» визначено повноваження місцевих державних адміністрацій у галузі соціального забезпечення та соціального захисту населення, зокрема щодо: реалізації державної політики в галузі соціального забезпечення та соціального захисту соціально незахищених громадян, призначення їм державної допомоги, надання адресної соціальної допомоги та підтримки; забезпечення працевлаштування інвалідів, сприяння здобуттю ними освіти, набуттю необхідної кваліфікації, матеріально-побутового обслуговування, санаторно-курортного лікування інвалідів; сприяння наданню протезно-ортопедичної допомоги населенню і забезпеченню інвалідів засобами пересування і реабілітації; встановлення піклування над повнолітніми дієздатними особами, які за станом здоров’я потребують догляду; сприяння громадським, релігійним організаціям, благодійним фондам, окремим громадянам у наданні допомоги соціально незахищеним громадянам; вирішення питання про утворення, реорганізацію та ліквідацію спеціальних будинків-інтернатів для осіб з інвалідністю; організації роботи медичних закладів по наданню допомоги населенню, надання у межах повноважень встановлених пільг і допомоги, пов'язаних з охороною материнства і дитинства, поліпшення умов життя інвалідів (ст. 22 закону [11]).

Згідно із ст. 17 п. 3 Закону України «Про місцеві державні адміністрації» [11] місцеві державні адміністрації: визначають необхідний рівень соціально-економічного забезпечення осіб з інвалідністю відповідно до нормативів мінімальних соціальних потреб; проводять розрахунок необхідного обсягу коштів та визначають ті послуги, які забезпечують мінімальний рівень потреб осіб з інвалідністю. Ст. 72 
Закону [12] встановлює, що місцеві державні адміністрації є підзвітними відповідним районним, обласним радам у виконанні програм соціально-економічного розвитку, зокрема щодо соціальноекономічного забезпечення осіб 3 інвалідністю, районних, обласних бюджетів, підзвітними $\mathrm{i}$ підконтрольними у частині повноважень, які делеговані їм відповідними районними, обласними радами, а також у виконанні рішень рад з цих питань.

Виконавчими органами сільських, селищних, міських, районних у містах рад $€$ їх виконавчі комітети, відділи, управління та інші створювані радами виконавчі органи, до відання яких віднесені питання соціально-економічного забезпечення осіб з інвалідністю. Ст. 34 Закону України «Про місцеве самоврядування в Україні» [12] визначено повноваження виконавчих органів сільських, селищних, міських рад у сфері соціально-економічного забезпечення осіб з інвалідністю, до відання яких у частині надання соціальних послуг належать: власні повноваження (встановлення за рахунок власних коштів $\mathrm{i}$ благодійних надходжень додаткових до встановлених законодавством гарантій щодо соціальноекономічного забезпечення осіб з інвалідністю; вирішення питань про надання допомоги інвалідам, інвалідам з дитинства у будівництві індивідуальних жилих будинків, проведенні капітального ремонту житла, у придбанні будівельних матеріалів; організація для інвалідів будинків-інтернатів, побутового обслуговування, продажу товарів у спеціалізованих магазинах і відділах за соціально доступними цінами, а також безоплатного харчування тощо); делеговані повноваження (забезпечення здійснення передбачених законодавством заходів щодо поліпшення житлових і матеріально-побутових умов інвалідів, які потребують обслуговування вдома, до влаштування в будинки інвалідів; вирішення питань про надання пільг і допомоги, пов'язаних з охороною материнства і дитинства інвалідів; встановлення розмірів і порядку виплати щомісячної допомоги особам, які здійснюють догляд за самотніми громадянами, які за висновком медичних закладів потребують постійного стороннього догляду тощо).

Такі інститути, як представницькі органи місцевого самоврядування (обласні, районні ради) здійснюють нормотворчу діяльність, розробляють, приймають відповідні правові акти, які регламентують питання соціально-економічного забезпечення осіб з інвалідністю на регіональному на місцевому рівнях державної політики та здійснюють контроль за їх виконанням.

Центральні органи виконавчої влади, діяльність яких пов'язана із соціально-економічним забезпеченням осіб з інвалідністю на регіональному рівні, слід віднести до відповідних територіальних органів, а саме: департаменти соціального захисту населення; департаменти економічного розвитку і торгівлі; департаменти охорони здоров'я; управління, сім'ї, молоді та спорту; служби в справах дітей; центри зайнятості та ін. Відповідно, функціональні повноваження таких територіальних органів розробляються та затверджуються на основі типових положень відповідних міністерств й інших центральних органів виконавчої влади.

До державних інститутів системи соціально-економічного забезпечення осіб з інвалідністю варто також віднести територіальні центри соціального обслуговування пенсіонерів та одиноких непрацездатних громадян, які $є$ спеціальними державними установами, що безпосередньо надають такі послуги інвалідам та іншим соціально незахищеним громадянам вдома, в умовах стаціонарного, тимчасового та денного перебування, які спрямовані на підтримання їхньої життєдіяльності і соціальної активності. Такі територіальні центри створюється, реорганізується та може бути ліквідованим за рішенням відповідного органу місцевої виконавчої влади за погодженням 3 регіональними управліннями праці та соціального захисту населення, до відання яких віднесено затвердження структур таких центрів. Територіальні центри утримується за рахунок коштів, що виділяються із місцевих бюджетів на соціальний захист населення, інших надходжень, в тому числі у вигляді прибутку від діяльності структурних підрозділів територіального центру, а також коштів благодійних фондів, пожертвувань окремих громадян, підприємств, установ тощо.

До ключових завдань територіальних центрів належать: виявлення осіб з інвалідністю, які потребують соціально-економічного забезпечення; встановлення зв'язків з підприємствами, установами, організаціями, незалежно від форм власності, з питань соціально-економічного забезпечення та надання допомоги особам із інвалідністю.

До складу таких територіальних центрів можуть входити: відділення соціальної допомоги вдома, у тому числі спеціалізовані - для обслуговування інвалідів з порушенням рухової активності, сліпих, глухих та ін.; відділення організації надання матеріальної грошової, натуральної адресної допомоги малозабезпеченим інвалідам; відділення соціально-побутової реабілітації інвалідів; відділення медикосоціальної реабілітації; стаціонарне відділення для постійного або тимчасового проживання інвалідів; спеціальні житлові будинки для одиноких осіб з інвалідністю, які містять комплекс служб соціальнопобутового і медичного обслуговування; лікувально-виробничі майстерні, спеціальні цехи, дільниці, підсобні господарства на госпрозрахунковій основі; їдальні, магазини, що діють на основі госпрозрахунку. 


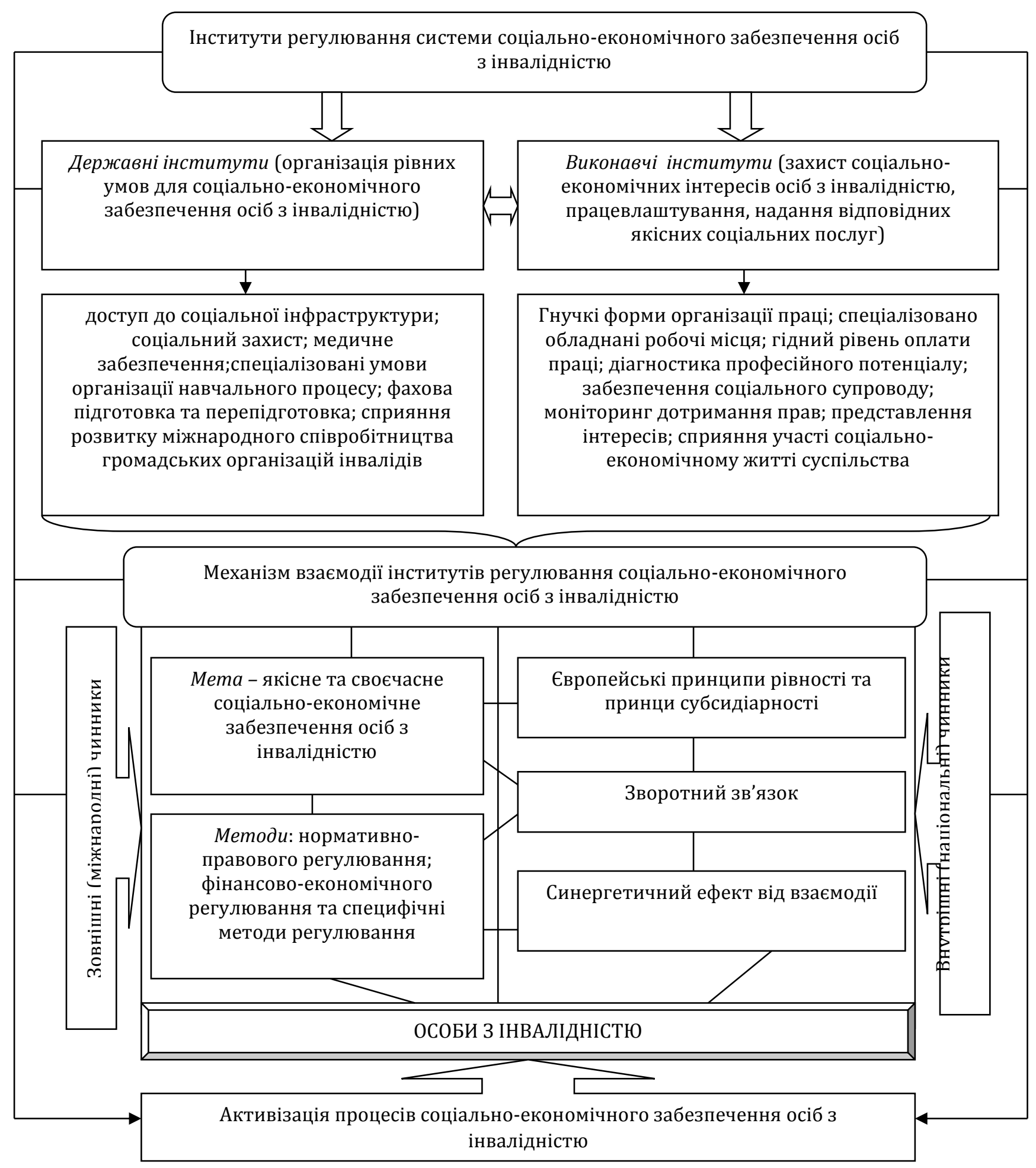

Рис. 1. Структурно-функціональна модель інституційного регулювання системи соціальноекономічного забезпечення осіб з інвалідністю*

*Розроблено автором.

До інститутів виконавчого (недержавного) сектору, діяльність яких пов'язана із соціальноекономічним забезпеченням осіб з інвалідністю варто віднести: громадські, благодійні, релігійні та інші організації, волонтерів; фізичні особи (підприємці), що надають відповідні соціальні послуги; установи та заклади комунальної власності, діяльність яких пов'язана із соціально-економічним забезпеченням осіб з інвалідністю. 
Систематизувати інститути такого сектору виявилося складно (рис. 1), адже існують об’єктивні труднощі в ідентифікації існуючих громадських об’єднань, діяльність яких пов'язана із соціальноекономічним забезпеченням осіб з інвалідністю. В Україні не ведеться статистичного обліку фізичних осіб, які надають соціальні послуги з метою соціально-економічного забезпечення осіб з інвалідністю. Установи та заклади комунальної власності, які надають відповідні соціальні послуги, знаходяться в підпорядкуванні органів місцевого самоврядування та відповідних органів виконавчої влади, які здійснюють управління ними. Управління інститутами виконавчого сектору, зокрема громадськими, благодійними і релігійними організаціями, здійснюється в порядку, визначеному законодавством i відповідними статутами.

\section{Висновки та перспективи подальших розвідок}

Проведене дослідження дозволило розробити структурно- функціональну модель інституційного регулювання системи соціально-економічного забезпечення осіб з інвалідністю, яка адаптована до умов функціонування національної економіки та ключовими концептуальними компонентами якої визначено: підвищення рівня якості життя осіб з інвалідністю (медичне, страхове та освітнє забезпечення); орієнтація на фахову підготовку та перепідготовку осіб 3 інвалідністю 3 метою підвищення рівня їх зайнятості та конкурентоспроможності на ринку праці; сприяння участі осіб 3 інвалідністю в соціально-економічному житті суспільства; активізація розвитку міжнародного співробітництва громадських та професійних об'єднань інвалідів.

\section{Список літератури}

1. Gryshova, I. Yu., Shestakovska, T. L., Glushko, O. V. The economic measurement of convergence of institutional impact on the sustainability of development / Scientific Papers of the Institute of Legislation of the Verkhovna Rada of Ukraine. - 2017. - №4 - pp.75-80.

2. Baimuratov M., Gryshova I., Akhmetova I. (2018) Leadership of Territorial Communities: Local and Global Factors. In: Strielkowski W., Chigisheva O. (eds) Leadership for the Future Sustainable Development of Business and Education. Springer Proceedings in Business and Economics. Springer, Cham. 179-188

3. Гришова, I. Ю. Сучасне формування системи управління персоналом як конкурентоздатність національної економіки / І. Ю. Гришова // Економічний форум. - 2016. - №1. - С. 340-347.

4. Шестаковська, Т. Л. Роль консюмеризму в соціально-економічних процесах / I. Ю. Гришова, Т. Л. Шестаковська // Наукові записки Інституту законодавства Верховної Ради України. - 2016. № 6. - С.75-82

5. Ніколюк, О. В. Вплив соціальної відповідальності бізнесу на конкурентоздатність підприємств аграрного сектору/ О. В. Ніколюк, Т. М. Гнатьєва // Вісник Чернігівського державного технологічного університету. - 2014. - № 4(76). - С. 151-157.

6. Ніколюк О.В. Удосконалення державного регулювання соціально-економічного захисту агробізнесу України // Вісник Сумського національного аграрного університету серія “Економіка та менеджмент”. - № 12 (66). - 2015. - С. 124-130.

7. Шаульська, Г. М. Громадськість як індикатор системи державного управління та громадянського суспільства. Public as indicator of the system of state administration and civil society // Вісник Київського національного університету імені Тараса Шевченка. - 2017. - № 1(8). - С. 66-69. Режим доступу: http://www.library.univ.kiev.ua/ukr/host/10.23.10.100/db/ftp/visnyk/derzh_uprav_8_2017.pdf.

8. Шаульська, Г. Органи місцевого самоврядування в умовах децентралізації механізмів влади: спроба концептуального аналізу [Електронний ресурс] / Г. Шаульська // Право та державне управління. 2016. - № 3. - Режим доступу: http://www.pdu-journal.kpu.zp.ua/issue-3-2016.

9. Про затвердження Положення про державну службу зайнятості: «Наказ Мінсоцполітики України від 20 січ. 2015 р. № 41» // Офіц. вісн. України. 2015. 20 лют. (№ 12). С. 283. Ст. 338.

10. Про Положення про Державну службу з питань інвалідів та ветеранів України : «Указ Президента України від 6 квіт. 2011 р. № 397/2011 (із змінами, внесен. згідно з Указом Президента в 2013 р.)» // Офіц. вісн. України. 2011. 26 квіт. (№ 29). - С. 99. Ст. 1232.

11. Про місцеві державні адміністрації: [Закон України від 9 квіт. 1999 р. № 586-XIV (із змінами і доповн. внесен. 44 Законами України у 2001-2015 рр.)] // Офіц. вісн. України. 1999. 21 трав. (№ 18). - Ст. 3.

12. Про місцеве самоврядування в Україні: [Закон України від 21 трав. 1997 р. № 280/97-ВР (із змінами і доповн. внесен. 87 Законами України у 1998- 2015 рр.)] // Відом. Верховної Ради України. 1997. 25 черв. (№ 24). Ст. 170.

13. Про затвердження типових положень (взірцевих) про територіальний центр соціального обслуговування «Наказ Мінсоцзахисту України від 1 квіт. 1997 р. № 44 (із змінами і допов., внесен. згідно із 2 Наказами Міністерства в 2007-2009 рр.)» // Офіц. вісн. України. 1997. 11 жовт. (№ 39). Ст. 57. 


\section{References}

1. Gryshova, I. Yu., Shestakovska, T. L., Glushko, O. V. (2017). The economic measurement of convergence of institutional impact on the sustainability of development. Scientific Papers of the Institute of Legislation of the Verkhovna Rada of Ukraine, 4, 75-80.

2. Baimuratov, M., Gryshova, I., Akhmetova, I. (2018). Leadership of Territorial Communities: Local and Global Factors. Leadership for the Future Sustainable Development of Business and Education. Springer Proceedings in Business and Economics, 179-188

3. Hryshova, I. Yu. (2016). Suchasne formuvannya systemy upravlinnya personalom yak konkurentozdatnist' natsional'noyi ekonomiky. Ekonomichnyy forum, 1, 340-347.

4. Gryshova, I. Yu., Shestakovs'ka, T. L. (2016). Rol' konsyumeryzmu v sotsial'no-ekonomichnykh protsesakh. Naukovi zapysky Instytutu zakonodavstva Verkhovnoyi Rady Ukrayiny, 6, 75-82.

5. Nikolyuk, O. V. \& Hnat'yeva, T. M. (2014). Vplyv sotsial'noyi vidpovidal'nosti biznesu na konkurentozdatnist' pidpryyemstv ahrarnoho sektoru. Visnyk Chernihivs'koho derzhavnoho tekhnolohichnoho universytetu, 4(76), 151-157.

6. Nikolyuk O. V. (2015). Udoskonalennya derzhavnoho rehulyuvannya sotsial'no-ekonomichnoho zakhystu ahrobiznesu Ukrayiny. Visnyk Sums'koho natsional'noho ahrarnoho universytetu, 12 (66), 124-130.

7. Shaul's'ka, H. M. (2017). Hromads'kist' yak indykator systemy derzhavnoho upravlinnya ta hromadyans'koho suspil'stva. Public as indicator of the system of state administration and civil society. Visnyk Kyyivs'koho natsional'noho universytetu imeni Tarasa Shevchenka, 1(8), 66-69. Retrieved from: http://www.library.univ.kiev.ua/ukr/host/10.23.10.100/db/ftp/visnyk/derzh_uprav_8_2017.pdf.

8. Shaul's'ka, H. (2016). Orhany mistsevoho samovryaduvannya v umovakh detsentralizatsiyi mekhanizmiv vlady: sproba kontseptual'noho analizu. Pravo ta derzhavne upravlinnya, 3. Retrieved from: http://www.pdu-journal.kpu.zp.ua/issue-3-2016.

9. Pro zatverdzhennya Polozhennya pro derzhavnu sluzhbu zaynyatosti. (2015). Nakaz Minsotspolityky Ukrayiny vid 20 sich. 2015 r. \# 41. Ofits. visn. Ukrayiny, 12, 283.

10. Pro Polozhennya pro Derzhavnu sluzhbu z pytan' invalidiv ta veteraniv Ukrayiny. (2013). Ukaz Prezydenta Ukrayiny vid 6 kvit. 2011 r. \# 397/2011 (iz zminamy, vnesen. z·hidno z Ukazom Prezydenta v 2013 r.). Ofits. visn. Ukrayiny, 29, 99.

11. Pro mistsevi derzhavni administratsiyi. (1999). Zakon Ukrayiny vid 9 kvit. 1999 r. \# 586-XIV (iz zminamy i dopovn. vnesen. 44 Zakonamy Ukrayiny u 2001-2015 rr.). Ofits. visn. Ukrayiny, 18, 3.

12. Pro mistseve samovryaduvannya v Ukrayini. (1997). Zakon Ukrayiny vid 21 trav. 1997 r. \# 280/97-VR (iz zminamy i dopovn. vnesen. 87 Zakonamy Ukrayiny u 1998- 2015 rr.). Vidom. Verkhovnoyi Rady Ukrayiny, 24, 170.

13. Pro zatverdzhennya typovykh polozhen' (vzirtsevykh) pro terytorial'nyy tsentr sotsial'noho obsluhovuvannya. (1997). Nakaz Minsotszakhystu Ukrayiny vid 1 kvit. 1997 r. \# 44 (iz zminamy i dopov., vnesen. z·hidno iz 2 Nakazamy Ministerstva v 2007-2009 rr.)» Ofits. visn. Ukrayiny, 39, 57.

Стаття надійшла до редакції 12.10.2018 р. 